\title{
Spiküle Meme Kanserlerinin Histopatolojik Moleküler Biyobelirteçler ve Manyetik Rezonans Görüntüleme Arasındaki Korelasyonu
}

\author{
Gökhan GÖKALP \\ Bursa Uludağ Üniversitesi Tıp Fakültesi Radyoloji Anabilim Dalı, Bursa.
}

\section{ÖZET}

Bu çalışmanın amacı spiküle ve spiküle olmayan meme kanserinin MRG ve histopatolojik bulguları arasındaki ilişkiyi karşılaştırmaktır. Ocak 2014 ile Ocak 2018 arasında, mamografide BI-RADS kriterlerine göre 50 spiküle ve 40 spiküle olmayan kitle olarak ultrasonografi kılavuzluğunda biyopsi veya lumpektomi/mastektomi yapılan 90 kadın çalışmaya alındı. Meme kanserinin moleküler biyobelirteçlerini tanımlamak için östrojen reseptörü (ÖR), progesteron reseptörü (PR), HER2 ekspresyonu ve Ki67 indeksi kullanıldı. Korelasyonların istatistiksel önemini ölçmek için Pearson ki-kare testi yapıldı. İki grup arasında yaş açısından fark yoktu ( $\mathrm{p}=0.331)$. Kitlelerin büyüklüğü iki grup arasında farklı değildi $(\mathrm{p}=0.244)$. Spiküle kitlelerde T2A görüntülerde (T2AG) daha fazla hipointens sinyal özelliği tespit edildi $(\mathrm{p}=0.004)$. MRG'de multifokal veya multisentrik tutulum, kitlesiz boyanma, periferik halkasal boyanma ve aksiller lenf nodu tutulumu açısından iki grup arasinda fark yoktu (sırasıyla $\mathrm{p}=0.237, \mathrm{p}=0.622, \mathrm{p}=0.096, \mathrm{p}=0.295 \mathrm{ve} \mathrm{p}=0.764$ ). ÖR ve PR pozitifliği spiküle kitlelerde daha yüksekti (sırasıyla $\mathrm{p}=0.027 \mathrm{ve} \mathrm{p}=0.03$ ). HER2 pozitifliği ve Ki67 indeksi için iki grup arasında istatistiksel olarak anlamlı bir fark bulunmadı (sırasıyla $\mathrm{p}=0.571$ ve $\mathrm{p}=0.596$ ). ÖR ve PR pozitifliği spiküle kitlelerde daha fazla olma eğilimindedir. $\mathrm{Bu}$, hastalığın seyrini ve tedavinin etkinliğini tahmin etmede yardımc olabilir.

Anahtar Kelimeler: Spikülasyon. Meme kanseri. Tümör belirteçleri. MRG.

Correlation between Histopathological Molecular Markers and Magnetic Resonance Imaging of Spiculated Breast Cancers

\begin{abstract}
To compare the relationship between MRI and histopathological findings of spiculated and non-spiculated breast cancer. Between January 2014 and January 2018, 90 women who had undergone ultrasonography guided biopsies or lumpectomy/mastectomy with 50 spiculated and 40 non-spiculated masses were separated accoding to BI-RADS criteria on mammography. Estrogen receptor (ER), progesterone receptor (PR), HER2 expression and Ki67 index were used as markers to identify molecular markers of breast cancer. Pearson chi-square test was employed to measure statistical significance of correlations. There was no difference for age between two groups ( $\mathrm{p}=0.331$ ). The size of the masses were not different between the two groups $(\mathrm{p}=0.244)$. More hypointense signal features were detected in T2-weighted images for the spiculated masses $(p=0.004)$. There was no difference between the two groups in terms of multifocal or multicentric involvement, non-mass type enhancement, peripheral rim enhancement and axillary lymph node involvement in the MRI $(p=0.237, p=0.622, p=0.096, p=0.295$ and $p=0.764$, respectively). ER and PR positivity were higher in the spiculated masses ( $p=0.027$ and $p=0.03$, respectively). For the HER2 positivity and Ki67 index, statistically significant a difference were not found between two groups ( $\mathrm{p}=0.571$ and $\mathrm{p}=0.596$, respectively). ER and PR positivity tends to be higher in the spiculated masses. This could be helpfull to predict the course of the disease as well as the effectiveness of the treatment.
\end{abstract}

Key Words: Spiculation, Breast cancer, Tumor receptor, MRI.

Meme kanseri, farklı histolojik ve biyolojik özelliklere sahip, morfolojik, klinik, hormon reseptör düzeyi ve tedaviye yanıtlarına göre değişken heterojen bir hasta1 lktır ${ }^{1}$.Heterojen bir grup oluşturan tümörlerin tek tip

Geliş Tarihi: 16.Şubat.2020

Kabul Tarihi: 17.Nisan.2020

Gökhan GÖKALP

Bursa Uludağ Üniversitesi Tıp Fakültesi

Radyoloji AD, Bursa.

Tel.: 05323757209

E-posta: drgokhangokalp@yahoo.com biyolojik davranış göstermesi beklenmeyeceği gibi, tedavi yanıtlarının da birbirinden farklı olması doğaldır. Malign meme tümörlerinin sinıflaması geleneksel olarak morfolojik görünümüne göre yapılmaktayken, günümüzde moleküler özelliklerine göre bazı alt tipler tanımlanmışıır ${ }^{2-4}$. "Gallen International Expert Consensus", meme kanserini, gen ekspresyon paternlerine dayanarak beş farklı moleküler alt tipte sinıflandırdı: luminalA (LA), luminal B [(LB; HER2-), LB (HER2 + )], insan epidermal büyüme faktörü reseptörü 2 (HER2) ve bazal benzeri (üçlü negatif). Patolojik olarak, bu moleküler subtipler tümör belirteçlerinin 
ekspresyon durumuna göre kategorize edilir: Östrojen reseptörü (ÖR), progesteron reseptörü (PR), HER2 ekspresyonu ve Ki-67 indeksi ${ }^{5}$. Meme kanserinin moleküler alt tiplendirilmesi, bireyselleştirilmiş hastaya özel tedavi planlaması için temel bir gereksinim haline gelmiştir ${ }^{6}$.

Radyojenomik, görüntüleme özelliklerini moleküler profillerle ilişkilendirmeyi amaçlayan yeni bir araştırma alanıdır ${ }^{7}$. Meme kanserinin biyolojik davranışını anlamak için yeni bir bakış açısı sunmaktadır. Meme kanserleri birçok faktörlere bağlı olarak çok çeşitli radyolojik özelliklerle karşımıza çıkabilir. "Görüntüleme Raporlama ve Veri Sistemi” (BI-RADS) sayesinde klinisyenlerle ortak bir dil ve standardizasyon sağlanmıştır. Spiküle kenarlı kitleler, BI-RADS’a göre, yüksek malign olasılıklı yani BI-RADS kategori-5 grubunda yer almaktadır. Bazı araştırmacılar son zamanlarda spiküle konturlu kitlelerin, luminal A alt tipinde diğerlerine göre daha yüksek oranda olduğunu bildirmişlerdir ${ }^{8}$. Bu nedenle çalışmamızda spiküle meme kanserlerinin, moleküler alt tipler ve manyetik rezonans görüntüleme (MRG) bulgularındaki özelliklere göre, spiküle olmayan kanserlerden farklılığını araştırmayı amaçladık.

\section{Gereç ve Yöntem}

\section{Hastalar:}

Ocak 2014 ile Ocak 2018 arasında, mamografiye göre 40 spiküle ve 50 spiküle olmayan kitleye, ultrasonografi (US) kılavuzluğunda kesici iğne biyopsisi veya lumpektomi/mastektomi yapılan toplam 90 hasta çalışmaya alındı. Spiküle kitlelerin ayırımı mamografide BI-RADS kriterlerine göre retrospektif olarak değerlendirildi. Tümör morfolojisi ve dinamik kontrastlı MRG bulguları, BI-RADS MRG sözlüğüne göre yapildi.

Çalışmamızda olguların dahil edilme kriterleri: 1) Biyopsi öncesi mamografi ve meme MRG incelemelerinin olması 2) Histopatolojik bilgilerin varlığı. Çalışmamızda olguların dışlanma kriterleri: 1) Erkek hasta cinsiyeti 2) Biyopsi öncesi neoadjuvan kemoterapi almas1 3) Başka bir merkezde biyopsi yapılması. Olguların hiçbirisi mamografi ve MRG incelemesinden önce kemoterapi veya radyoterapi görmedi. Tüm hastalara MR çekiminden sonra 2 ay içinde biyopsi yapılmıştı.

Meme kanserinin moleküler alt tiplerini tanımlamak için ÖR, PR, HER2 ekspresyonu ve Ki67 indeksi belirteç olarak kullanıldı. Tümörlerin tipi, boyutu, grade, ÖR, PR, HER 2 ekspresyonu ve Ki67 indeks değerleri olguların patoloji raporlarından kayıt edildi. ÖR ve PR reseptörleri, \%10 ve üzerindeki değerlerin olmas1 durumunda pozitif kabul edildi. HER2 pozitif veya negatifliği not edildi. Ki67 indeksi, kitlelerin hücre proliferasyon fraksiyonunu gösterir ve çalışma- mızda $\geq \% 14$ olması durumunda pozitif olarak kabul edilmiştir.

Çalışmamız Klinik Araştırmalar Etik Kurulu'muz tarafindan onaylanmıştır (05.Şubat.2020-Karar No: 2020-2/18).

\section{Görüntüleme Tekniği}

\section{Çekim Protokolü}

Mamografik incelemeler Siemens Dimensions (Hologic, Bedford, ABD) 2B mamografi cihazında gerçekleştirildi. Mamografiler rutin olarak kranio-kaudal (CC) ve medio-latero-oblik (MLO) projeksiyonunda alınarak değerlendirildi. Gereklilik halinde spot kompresyon ve magnifikasyon mamografileri elde olundu. Görüntüler, iş istasyonunda PACS arşivi kullanılarak, yüksek rezolüsyonlu monitörlerde değerlendirildi. Raporlamada “Amerikan Radyoloji Koleji” (ACR) BI-RADS sözlüğü kullanıldı. Mamogramda kitle olan hastalar kitlenin kenar özelliğine göre spiküle ve spiküle olmayan gruplara ayrıldı. Kenarlarından parankime 1şınsal tarzda çizgisel uzantıları olan kitleler spiküle kenarlı kabul edildi. Spiküle kenarlı olmayanlar düzgün, düzensiz, mikrolobole ve kenarları belirsiz kitlelerdi. Eğer kitlelerin kenarları özelikle dens meme nedeniyle zor tespit ediliyorsa spiküle olmayan gruba alınd.

Hastaların MRG tetkikleri Radyoloji Kliniğimizde 3T MRG cihazı (Philips Achiva, Philips Medikal Sistem, Hollanda) ile yapıldı. Olgular dedike meme sargısı ile pron pozisyonunda MRG cihazına yerleştirildi. 300 mm görüntüleme alanı (FOV) kullanıldı. T1-ağırlıklı görüntü (T1AG) TSE (TR 4000, TE 10) ve T2ağırlıklı görüntü (T2AG) TSE (TR 5000, TE 120) sekansları $3 \mathrm{~mm}$ kesit kalınlığında aksiyel planda yapıldı. T1-ağırlıklı THERIVE 3-boyutlu (TR/TE 4.6/2.3ms) sekansı ile $1 \mathrm{~mm}$ kesit kalınlığında aksiyel planda prekontrast ve dinamik postkontrast görüntüler elde edildi (1 dk). Kontrast madde IV olarak $0,1 \mathrm{mmol} / \mathrm{kg}$ dozda verildi. Dinamik incelemelerde kontrastsız alınan görüntüleri takiben, otomatik enjektörle $0,1 \mathrm{mmol} / \mathrm{kg}$ IV kontrast madde (Gadopentate dimeglumine) saniyede $3 \mathrm{ml}$ hıla gidecek şekilde enjekte edildi ve daha sonra aynı bölge ardarda $6 \mathrm{kez}$ daha görüntülenerek dinamik çalışma yapıldı. İnceleme süresi ortalama $15 \mathrm{dk}$. sürdü. İnceleme sonunda kontrast tutulumunun daha belirgin ortaya çıkarılabilmesi için cihazın standart çıkartma fonksiyonu kullanılarak tüm kontrastlı kesitler, kontrastsız kesitlerden otomatik olarak tek tek çıkarılarak "substraksiyon" görüntüler elde edildi. Görüntüler iş istasyonuna aktarilarak incelendi. 
Spiküle Meme Kanserleri

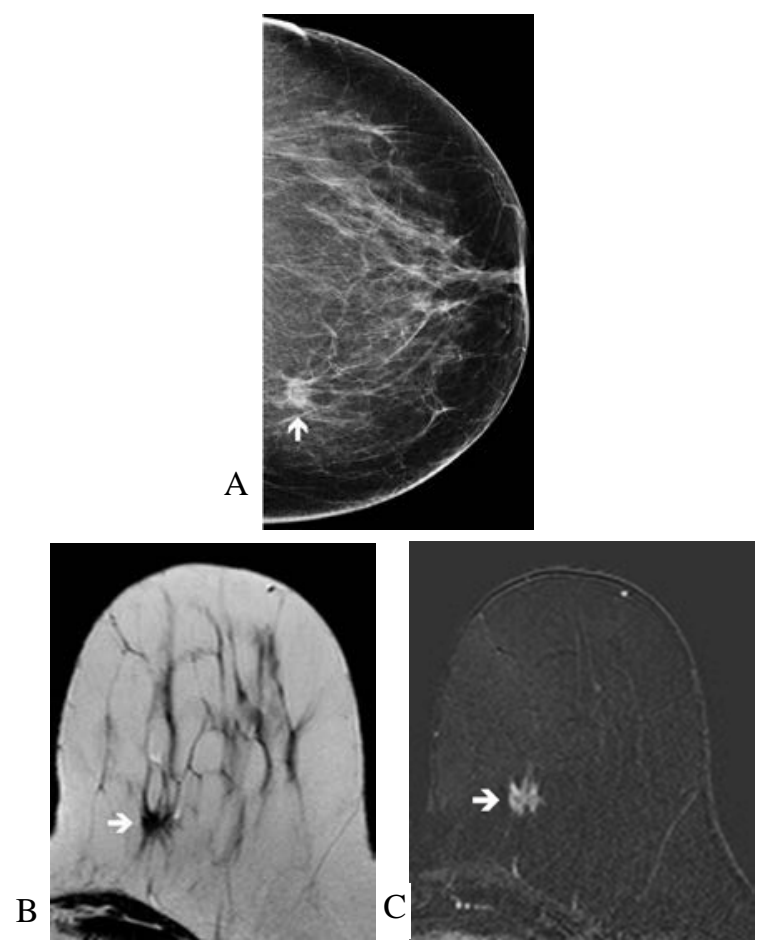

Şekil 1:

Sol meme 60 yaşında, $10 \mathrm{~mm}$ boyutunda, patolojik grade 1 invazivlobüler karsinom. A. Mamografide, sol meme CC projeksiyonda iç kadranda spikülekonturlu

kitle izleniyor (ok). B.MRG'de, T2AG'de kitlenin glandüler dokulara göre hipointens sinyal özelliğinde olduğu görülüyor (ok). C. Dinamik kontrastlı MRG'de multifokal-multisentrik tutulum, kitlesiz tip boyanma, periferik halkasal boyanma izlenmedi (ok). Histopatolojik analizde, ÖR pozitif (\%100), PR pozitif ( \%90), HER 2 negatif ve Ki67 100/1000.

\section{Görüntülerin Analizi}

Kitlelerin mamografi ve MRG özellikleri 12 yıllık deneyimli meme radyoloğu tarafından, klinik bilgi ve patoloji sonuçları (moleküler alt tipler) bilinmeden değerlendirildi. Mamografide malign olan kitleler spiküle ve spiküle olmayan olarak ayrıldı.

MRG'de BI-RADS MR'a göre aşağıdaki özellikler değerlendirildi:

a.Morfoloji (T1AG ve T2AG'de boyut, şekil, kontur ve sinyal özelliği)

b.Dinamik kontrastlı çalışma

-Periferik halkasal boyanma

-Multifokal veya multisentrik tutulum

-Kitlesiz boyanma

c. Aksiller lenf nodu tutulumu

Kitlelerin hepsine US eşliğinde kesici iğne biyopsisi (16G) yapıldı ve histopatolojik sonuçlar elde olundu. MRG özellikleri histopatolojik bulgular ile karş1laşt1rildi.

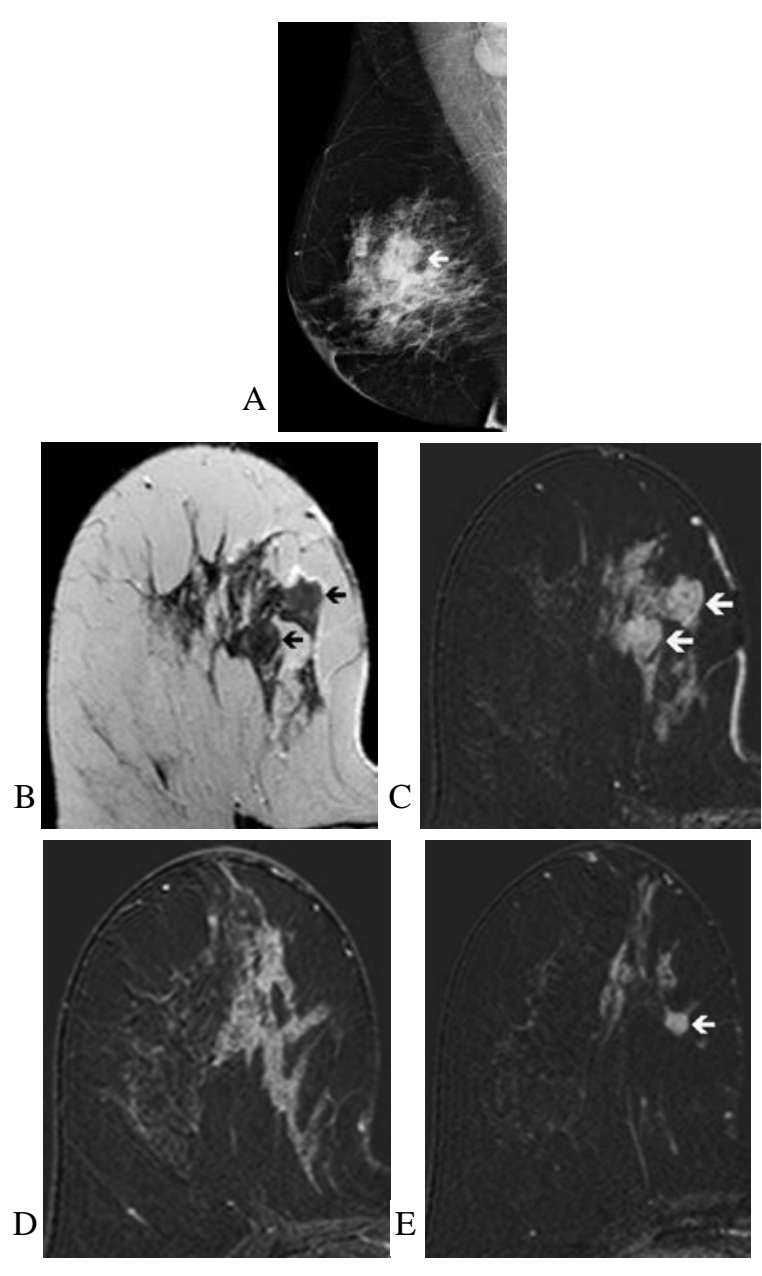

Şekil 2:

Să̆ meme 52 yaşında, 17 mm boyutunda, patolojik grade 2 invazivduktal karsinom. A. Mamografide, să meme MLO projeksiyonda düzensiz konturlu kitle izleniyor (ok). Aynı zamanda aksiller bölgede atipik lenf nodu mevcut. B.MRG'de, T2AG'de kitlenin glandüler dokulara göre izointens sinyal özelliğinde olduğu görülüyor (oklar). C. Dinamik kontrastlı MRG'de, alt iç kadranda multifokal 2 adet kitle izleniyor (oklar).

D. Kitleler dışında iç kadranda segmental tarzda kitlesiz boyanma görülüyor. E. Üst iç kadranda bir başka kontrast tutan kitle (multisentrik) mevcut (ok).Histopatolojik analizde, ÖR negatif, PR negatif, HER 2 pozitif ve Ki67 80/1000.

\section{İstatistiksel Analiz}

Korelasyonların istatistiksel anlamlılığını ölçmek için Pearson ki-kare testi kullanıldı. Ayrıca, spiküle kitlenin varlığını veya yokluğunu etkileyebilecek faktörlerin nispi katkısını ölçmek için iki değişkenli bir lojistik regresyon modeli oluşturuldu. İstatistiksel olarak anlamlı bir farkı belirtmek için 0,05 'ten küçük bir $p$ değeri kabul edildi. Tüm istatistiksel analizler SPSS 21.0 (SPSS Inc, Chicago, IL) proğramı kullanılarak gerçekleştirildi. 


\section{Bulgular}

Hastaların yaşları spiküle ve spiküle olmayan kitle grupları için sırasıyla 30 ve 83 yaş (ortalama yaş: 53,46 y1l) ve 33-82 yaş (ortalama yaş: 55,57 y1l) arasında değişmekteydi. Gruplar arasında yaşlara göre istatistiksel olarak anlamlı fark yoktu $(\mathrm{p}=0.331)$. MRG'de spiküle ve spiküle olmayan kitle grupları için lezyonların boyutu sirasıyla 10-66 $\mathrm{mm}$ arasında (ortalama $25 \mathrm{~mm}$ ) ve $7-55 \mathrm{~mm}$ arasinda (ortalama 22.2 $\mathrm{mm}$ ) idi. Kitlelerin boyutuna göre gruplar arasında istatistiksel olarak anlamlı fark yoktu $(\mathrm{p}=0.244)$, (Tablo I).

Spiküle kitlelerin histopatolojik bulguları, invaziv duktal karsinom ( $\mathrm{n}=42, \% 86)$, invaziv lobüler karsinom $(n=4, \% 8)$, diğer $(n=4, \% 8)$ ve spiküle olmayan kitleler, invaziv duktal karsinom ( $\mathrm{n}=36, \% 90)$, invaziv lobüler karsinom $(n=2, \% 5)$, diğer $(n=2, \% 5)$ idi.

Patolojik grade 1,2,3 bakımından her iki grup arasında farklılık saptanmadı $(p=0.719)$. Spiküle $(\% 78)$ ve spiküle olmayan (\%70) her iki grupta da grade 2 daha fazla görüldü.

MRG'de multifokal-multisentrik tutulum, kitlesiz tip boyanma, periferik halkasal boyanma ve aksiller lenf nodu tutulumu açısından iki grup arasında fark yoktu (sirasiyla $\mathrm{p}=0.237, \mathrm{p}=0.622, \mathrm{p}=0.096, \mathrm{p}=0.295$ ve $\mathrm{p}=0.764)$. Sadece MRG'de, spiküle meme kitlelerin sinyal intensitesi T2AG'de daha düşük bulundu $(p=0.004)$, (Tablo I).

Tablo I. Kitlelerin demografik özellikleri ve MRG bulguları

\begin{tabular}{|l|c|c|c|}
\hline & Spiküle şekilli kitleler & $\begin{array}{c}\text { Spiküle şekilli } \\
\text { olmayan kitleler }\end{array}$ & $\begin{array}{c}P \\
\text { değeri }\end{array}$ \\
\hline Yaş $^{\star}$ & $53,46(30-83 ; 10,13)$ & $55,57(33-82 ; 10,27)$ & 0,331 \\
\hline Boyut*(mm) & $25(10-66 ; 11,49)$ & $22,22(7-55 ; 10,67)$ & 0,244 \\
\hline $\begin{array}{l}\text { T2AG'de düşük } \\
\text { sinyal intensitesi }\end{array}$ & $28(\% 56)$ & $9(\% 22,5)$ & 0,04 \\
\hline Multifokal & $20(\% 40)$ & $21(\% 52,5)$ & 0,237 \\
\hline Multisentrik & $8(\% 16)$ & $8(\% 20)$ & 0,622 \\
\hline $\begin{array}{l}\text { Periferik halka- } \\
\text { sal boyanma }\end{array}$ & $7(\% 14)$ & $9(\% 22,5)$ & 0,295 \\
\hline Kitlesiz boyanma & $4(\% 8)$ & $8(\% 20)$ & 0,096 \\
\hline $\begin{array}{l}\text { Aksiller lenf } \\
\text { nodu }\end{array}$ & $16(\% 32)$ & $14(\% 35)$ & 0,764 \\
\hline
\end{tabular}

*ortalama (minimum-maksimum; standart deviasyon)

ÖR ve PR pozitifliği spiküle kitlelerde fazlaydı (sırasiyla $\mathrm{p}=0.027$ ve $\mathrm{p}=0.03$ ). ÖR, spiküle meme kanserlerinde \%92 pozitif iken, spiküle olmayan grupta \%75 pozitifdi. PR, spiküle meme kanserlerinde \%78 pozitif iken, spiküle olmayan grupta \%57.5pozitifdi (Tablo II).
Tablo II. Kitlelerin histopatolojik bulguları

\begin{tabular}{|c|c|c|c|c|c|c|c|}
\hline & \multicolumn{3}{|c|}{ Spiküle şekilli kitleler } & \multicolumn{3}{|c|}{$\begin{array}{l}\text { Spiküle şekilli olmayan } \\
\text { kitleler }\end{array}$} & $\begin{array}{c}P \\
\text { değeri }\end{array}$ \\
\hline Grade & \begin{tabular}{|l|} 
Grade1 \\
$(7 ; \% 14)$ \\
\end{tabular} & $\begin{array}{c}\text { Grade2 } \\
(39 ; \% 78) \\
\end{array}$ & $\begin{array}{l}\text { Grade3 } \\
(4 ; \% 8) \\
\end{array}$ & $\begin{array}{l}\text { Grade1 } \\
(8 ; \% 20) \\
\end{array}$ & \begin{tabular}{|c|} 
Grade2 \\
$(28 ; \% 70)$ \\
\end{tabular} & $\begin{array}{l}\text { Grade3 } \\
(4 ; \% 10)\end{array}$ & 0,719 \\
\hline $\begin{array}{c}\text { ÖR } \\
\text { reseptör (+) }\end{array}$ & & $46(\% 92)$ & & & $30(\% 75)$ & & 0,027 \\
\hline \begin{tabular}{c|}
$P G$ \\
reseptör (+)
\end{tabular} & & $39(\% 78)$ & & & $23(\% 57,5)$ & & 0,037 \\
\hline HER $2(+)$ & & $9(\% 18)$ & & & $9(\% 22,5)$ & & 0,596 \\
\hline $\begin{array}{c}\text { Ki67 } \\
(\geq \% 14)\end{array}$ & & $22(\% 44)$ & & & $20(\% 50)$ & & 0,571 \\
\hline
\end{tabular}

HER2 pozitifliği ve Ki67 indeksi açısından istatiksel olarak iki grup arasında farklılık yoktu (sırasıyla $\mathrm{p}=0.571$ ve $\mathrm{p}=0.596$ ). Ki67 indeksi, spiküle meme kanserlerinde \%44 iken, spiküle olmayan grupta \%50 idi. HER2 ekspresyonu spiküle meme kanserlerinde \%18 pozitif iken, spiküle olmayan grupta \%22.5 pozitifdi (Tablo II). MRG bulguları ve histopatolojik analiz ile ilgili örnekler Şekil 1 ve Şekil 2'de sunulmuştur.

\section{Tartışma}

Erken tanı yöntemlerinin gelişmesi ve tedavilerdeki ilerlemelere rağmen, meme kanseri halen önemli bir mortalite ve morbidite nedenidir. Histolojik olarak birçoğu invazivduktal karsinom olmasına rağmen, biyolojik davranış olarak geniş bir yelpazede dağılan heterojen bir hastalıktır. Her alt tip farklı insidans, prognoz, tedaviye cevap, metastaz, nüks veya hastalıksız sağkalım özellikleri gösterir ${ }^{10,11}$.

Meme kanserlerinin subtiplerinden en fazla görülen ve prognozu en iyi luminal olarak adlandırılan gruptur. Memenin duktus ve asinüslerin dekiluminal yüzde yer alan hücrelerin salgıladığı proteinleri ekspresse ederler $^{12}$. Bu grupta ÖR ve/veya PR pozitiftir. Bu durum tedavi protokollerini belirler ve değiştirir. ÖR/PR pozitif meme kanseri, ÖR/PR negatif meme kanserine göre daha kötü klinik sonuçlara ve daha kısa sağkalım oranına sahiptir ${ }^{13}$. ÖR pozitif hücrelerin daha iyi diferansiye, daha az agresif ve östrojen reseptör blokerleri veya aromataz inhibitörleri gibi daha fazla terapötik seçeneğe sahiptir ${ }^{13,14}$

ÖR pozitif kanserin daha az agresif olması muhtemelen daha düşük hücresel farklılaşma ve anjiyogenez nedeniyledir. Koukourakis ve ark., ÖR ekspresyonu ile mikrovasküler yoğunluğun ters bir ilişki olduğunu bildirmişlerdir ${ }^{15}$. Menopoz sonrası hastalarda, ÖR negatif tümörlerde daha yüksek oranda "vaskülerendotel büyüme faktörü” (VEGF) pozitif hücre bulundu. Bu durum, ÖR negatif tümörlerin daha yüksek proliferatif aktivite ile karakterize olduklarını gösterir ${ }^{16}$.

Önceki çalışmalar, mamografik görünümün moleküler alt tip ile korele olabileceğini ve meme tümörünün biyolojik davranışını anlamak için yeni bir 


\section{Spiküle Meme Kanserleri}

bakıș açısı sağlayabileceğini göstermektedir. Radyolojik olarak luminal subtiplerin görünüşleri diğer subtiplerden değişkenlik gösterebilirr ${ }^{17-18}$.

Spikülasyon çevredeki parankimde desmoplastik veya fibrotik reaksiyona bağlı olarak düşük ve orta dereceli tümörlerde görülür. Mamografide invaziv meme kanserinin karakteristik bir görünümü olarak kabul edilir. Birçok faktör spikülasyona katkıda bulunabilir. Bunlardan birisi, normal Cooper bağlarının tümör tarafından çekilmesi (desmoplazi) veya tümör hücrelerinin çevreleyen dokuya yayılmasıdır. İkincisi, stromal doku ile daha fazla etkileşim sonucu yağ doku invazyonudur ${ }^{8-19}$.

Spikülasyon, mamografide invaziv meme kanserinin karakteristik bir görünümü ve hastalığın tanısında iyi bilinen bir kriterdir. Özellikle, bazı araştırmacılar yakın zamanda, spiküle kenarlı kitlelerin, lümen A meme kanserli hastalarda, diğer alt tiplere sahip olanlardan önemli ölçüde daha yaygın olduğunu ve hastalık için bağımsız ve iyi bir prognostik faktör olabileceğini bildirdi ${ }^{8-19}$. Bununla birlikte, mekanizma ve spiküle kitlelerde bunu etkileyen faktörlerle ilgili sorular cevapsız kalmıştır.

Yüksek ÖR veya PR pozitif oranlar1, HER2 negatifliği ve düşük Ki67 indeksini içeren çeşitli faktörlerin spikülasyonun oluşmasına katkıda bulunduğuna inanılmaktadır $^{2-21}$. Liu S ve ark. çalışmasında, spiküle kitlelerde hormon reseptörlerinin pozitif ekspresyonu, HER2 negatif ve düşük Ki67 proliferatif aktiviteyi daha fazla saptadilar ${ }^{8}$. Spiküle kitlelerde HER2 pozitifliğine rastlamadılar. Diğger bir çalışmada ÖR negatif tümörlerin spikülekonturlu olmayan kitlelelerde olduğunu bildirdiler ve HER2 pozitifliğini daha fazla buldular $^{22}$. Çalışmamızda spiküle kitlelerde HER2 ekspresyonu bakımından diğer gruba göre belirgin bir farklılık yoktu. Spiküle olan kitlelerde ÖR ve PR pozitif oranları, spiküle olmayan kitlelere göre daha yüksekti. Bu durum, diğer çalışmalarla korele bir şekilde luminal alt moleküler grubun spiküle kitlelerde daha fazla olduğunu gösterir. Radyolojik görüntülemelerde, spiküle bir kitle saptadığımızda, moleküler alt tip olarak luminal grupta olduğunu düşünüp, yani ÖR ve PR pozitif olduğunu varsayarak prognozun daha iyi ve hormonal tedaviye yanıt alınabileceğini öngörebiliriz.

Liu S ve ark., düşük ve orta histolojik dereceli tümörler ile spiküle kitlenin varlığı arasında istatistiksel olarak anlamlı bir ilişki gözlemlediler ${ }^{8}$. Bazı araştırmacılar düşük histolojik tümör derecesinin spikülasyonun nedenlerinden biri olduğunu bildirmiştir ${ }^{20-21}$. Çalışmamızda ise histolojik grade bakımından her iki grup arasında farklılık saptanmadı $(\mathrm{p}=0.719)$. Spiküle (\%78) ve spiküle olmayan (\%70) her iki grupta da grade 2 daha fazla görüldü.

Meme kanserlerinin moleküler alt tiplerinin MRG'de farklı görüntüleme özellikleri gösterdiği saptanmış$\operatorname{tır}^{12,18,23,24}$. Bu durum, MRG'de meme kanserinin prognozunun öngörüsünde yardımcı olabilir. ÖR negatif kanser; daha agresif, daha büyük tümör boyutu ve tümöral infiltrasyon şeklinde kitlesiz boyanma özellikleri gösterir. ÖR negatif kanser; periferik halkasal boyanma, erken pik ve yıkanma tarzında boyanma eğrisi daha fazla gösterir, ancak bu istatistiksel anlamlılığa ulaşmamıştır. Dinamik kontrastlı çalışmanın ilkinde erken pik ve periferik halkasal boyanma rölatif kötü prognozu gösterir. Bu görüntüleme özellikleri, daha az hücresel farklılaşma ve/veya daha yüksek bir anjiyojenik aktivite ile ilişkilendirilebilir ${ }^{25,26}$.

ÖR negatif hastalarda daha fazla metastatik lenf nodu görülür ve neoadjuvan kemoterapi olasılığı daha yüksektir. Chen JH ve ark. çalışmasında ise, MRG'de patolojik aksiller nodal tutulum ile ÖR pozitif ve negatif hastalar arasında anlamlı farkl1lık bulmadılar ${ }^{13}$. Çalışmamızda MRG'de, multifokal-multisentrik tutulum, kitlesiz boyanma, periferik halkasal boyanma ve aksiller lenf nodu tutulumu bakımindan iki grup arasinda farklılık saptanmadi $(\mathrm{p}>0.05)$. Ancak spiküle olmayan kitlelerde tanımlanan bu MRG özellikleri daha fazla görüldü.

MRG'de T2A görüntülerde meme tümörleri genellikle düşük sinyal intensitesinde görülür. T2A görüntülerde hiperintens sinyal daha çok benign kitlelerde olur ancak bu durum düzensiz ve spiküle kitleler için benignitenin uygun bir belirteci değildir ${ }^{27,28}$. Çalışmamızda olduğu gibi spiküle kitleler, muhtemelen desmoplastik reaksiyonun oluşumuna daha fazla zaman olduğundan ve bunun sonucu fibrozis ile daha çok düşük sinyal intensitesinde olma eğilimindedir.

Çalışmamızın bazı kısıtlamaları vardı. İlk olarak, çalışma retrospektif olarak yapıldı. İkincisi, histopatolojik bulguların hepsi lumpektomi veya mastektomi materyalinden elde olunmad1.

Sonuç olarak, spiküle bir kitlenin varlığında, meme kanserinin histopatolojik olarak ÖR ve PR pozitif (Luminal A ve B alt tipi ile ilişkili) olasılığının daha fazla ve prognozun daha iyi olabileceğini öngörebiliriz.

\section{Kaynaklar}

1. Lam SW, Jimenez CR, Boven E. Breast cancer classification by proteomic technologies: current state of knowledge. Cancer Treat Rev 2014;40:129-38.

2. Beral V, Bull D, Doll R, Peto R, Reeves G. Breast cancer and breastfeeding: Collaborative reanalysis of individual data from 47 epidemiological studies in 30 countries, including 50302 women with breast cancer and 96973 women without the disease. Lancet 2002;360;187-95.

3. Yersal O, Barutca S. Biological subtypes of breast cancer: Prognostic and therapeutic implications. World J Clin Oncol 2014;5:412-24.

4. Guiu S, Michiels S, André F, Cortes J, Denkert C, Di Leo A, et al. Molecular subclasses of breast cancer: how do we define them? The IMPAKT 2012 Working Group Statement. Ann Oncol 2012;23:2997-3006.

5. Burstein HJ, Curigliano G, Loibl S, Dubsky P, Gnant M, Poortmans $\mathrm{P}$ et al. Estimating the benefits of therapy for early- 
stage breast cancer: the St. Gallen International Consensus Guidelines for the primary therapy of early breast cancer 2019 Ann Oncol 2019; 30(10): 1541-1557.

6. Jin YH, Hua QF, Zheng JJ, Ma XH, Chen TX, Zhang S et al. Diagnostic Value of ER, PR, FR and HER-2-Targeted Molecular Probes for Magnetic Resonance Imaging in Patients with Breast Cancer. Cell Physiol Biochem. 2018;49:271-81.

7. Woodard GA, Ray KM, Joe BN, Price ER. Qualitative Radiogenomics: Association between Oncotype DX Test Recurrence Score and BI-RADS Mammographic and Breast MR Imaging Features. Radiology. 2018 Jan;286:60-70.

8. Liu S, Wu XD, Xu WJ, Lin Q, Liu XJ, Li Y. Is There a Correlation between the Presence of a Spiculated Mass on Mammogram and Luminal A Subtype Breast Cancer? Korean J Radiol. 2016;17:846-52.

9. Boisserie-Lacroix M, Bullier B, Hurtevent-Labrot G, Ferron S, Lippa N, Mac Grogan G. Correlation between imaging and prognostic factors: molecular classification of breast cancers. Diagn Interv Imaging. 2014;95:227-33.

10. Trop I, LeBlanc SM, David J, Lalonde L, Tran-Thanh D, Labelle M, et al. Molecular classification of infiltrating breast cancer: toward personalized therapy. Radiographics. 2014;34:1178-95.

11. Alili C, Pages E, Curros Doyon F, Perrochia H, Millet I, Taourel P. Correlation between MR imaging - prognosis factors and molecular classification of breast cancers. Diagn Interv Imaging. 2014 Feb;95(2):235-42.

12. Ha R, Jin B, Mango V, Friedlander L, Miloshev V, Malak S, et al. Breast cancer molecular subtype as a predictor of the utility of preoperative MRI. AJR 2015;204:1354-60.

13. Chen JH, Baek HM, Nalcioglu O, Su MY. Estrogen receptor and breast MR imaging features: a correlation study. J Magn Reson Imaging 2008;27(4):825-33.

14. Cho N. Molecular subtypes and imaging phenotypes of breast cancer. Ultrasonography. 2016;35:281-8.

15. Koukourakis MI, Manolas C, Minopoulos G, Giatromanolaki A Sivridis E. Angiogenesis relates to estrogen receptor negativity, c-erbB-2 overexpression and early relapse in node-negative ductal carcinoma of the breast. Int J Surg Pathol 2003;11:29-34.

16. Fuckar D, Dekanic A, Stifter S, Mustać E, Krstulja M, Dobrila $\mathrm{F}$, et al. VEGF expression is associated with negative estrogen receptor status in patients with breast cancer. Int J Surg Pathol 2006;14:49-55.

17. Killelea BK, Chagpar AB, Bishop J, Horowitz NR, Christy C, Tsangaris $\mathrm{T}$, et al. Is there a correlation between breast cancer molecular subtype using receptors as surrogates and mammographic appearance? Ann Surg Oncol 2013;20:3247-53.

18. Grimm LJ, Mazurowski MA. Breast Cancer Radiogenomics: Current Status and Future Directions. Acad Radiol. 2020;27:3946

19. Evans AJ, Pinder SE, James JJ, Ellis IO, Cornford E. Is mammographic spiculation an independent, good prognostic factor in screening-detected invasive breast cancer? AJR 2006;187:1377-80.

20. Jiang L, Ma T, Moran MS, Kong X, Li X, Haffty BG, et al. Mammographic features are associated with clinicopathological characteristics in invasive breast cancer. Anticancer Res 2011;31:2327-34.

21. Moriuchi H, Yamaguchi J, Hayashi H, Ohtani H, Shimokawa I, Abiru H, et al. Cancer cell interaction with adipose tissue: correlation with the finding of spiculation at mammography. Radiology 2016;279:56-64.

22. Shin HJ, Kim HH, Huh MO, Kim MJ, Yi A, Kim H, et al. Correlation between mammographic and sonographic findings and prognostic factors in patients with node-negative invasive breast cancer. Br J Radiol 2011;84:19-30.

23. Wu M, Zhong $\mathrm{X}$, Peng $\mathrm{Q}$, Xu M, Huang $\mathrm{S}$, Yuan J, et al.Prediction of molecular subtypes of breast cancer using BIRADS features based on a "white box" machine learning approach in a multi-modal imaging setting. Eur $\mathrm{J}$ Radiol. 2019;114:175-184.

24. Montemezzi S, Camera L, Giri MG, Pozzetto A, Caliò A, Meliadò $\mathrm{G}$, et al.Is there a correlation between 3T multiparametric MRI and molecular subtypes of breast cancer? Eur J Radiol. 2018;108:120-7.

25. Schmitz AM1, Loo CE, Wesseling J, Pijnappel RM, Gilhuijs KG. Association between rim enhancement of breast cancer on dynamic contrast-enhanced MRI and patient outcome: impact of subtype. Breast Cancer Res Treat. 2014;148:541-51.

26. Jinguji M, Kajiya Y, Kamimura K, Nakajo M, Sagara Y, Takahama T, et al. Rim enhancement of breast cancers on contrastenhanced MR imaging: relationship with prognostic factors. Breast Cancer. 2006;13:64-73.

27. Gokalp G, Topal U, Yildirim N, Tolunay S. Malignant spiculated breast masses: dynamic contrast enhanced MR (DCE-MR) imaging enhancement characteristics and histopathological correlation. Eur J Radiol 2012;81:203-8.

28. Macura KJ, Ouwerkerk R, Jacobs MA, Bluemke DA. Patterns of enhancement on breast MR images: interpretation and imaging pitfalls. Radiographics. 2006;26:1719-34 